\title{
Anti-Synepthelichorial Placenta Scfv Library Construction
}

\author{
Paulo Henrique Costa de Lima ${ }^{1 *}$ and Luiz Augusto Vieira Cordeiro ${ }^{2}$ \\ ${ }^{1}$ Federal Institute of Education, Science and Technology of Amazonas - IFAM, Brazil \\ ${ }^{2}$ Department of Animal Sciences, Rural Federal University of Semi Arid - UFERSA, Brazil
}

Received: 眥 April 09, 2018; Published: 制 April 17, 2018

*Corresponding author: Paulo Henrique Costa de Lima, Federal Institute of Education, Science and Technology of Amazonas IFAM, 69880-000, Eirunepé, State of Amazonas, Brazil

\begin{abstract}
Hens were immunized with a macerate of goat and sheep placentomes. Immunizations were repeated every 15 days. Eggs were collected over a period of 03 immunizations, IgY isolated, and its concentration measured. After 45 days of the start of immunization, chickens were euthanized, their spleens isolated and fragmented for total RNA extraction by Trizol method. Performed the synthesis of cDNA, was amplified by PCR the fragments of immunoglobulin G avian variable light chain (VL) and heavy chain (VH). Fragments of VL and VH were used to constitute the final product by recombinant PCR-overlap process. The results present the feasibility of building a library of scFv anti goats and sheep placenta opening the possibility of manufacture diagnostic kits for various physiological situations of placental trophoblast cells belonging to these species.
\end{abstract}

Keywords: Trophoblast Cells, Placentomes, Syneptheliochorial, Cell Markers

\section{Introduction}

The developments of the techniques of molecular biology and genetic engineering have provided the emergence of recombinant DNA technology has enabled the production of several new molecules of immunoglobulin fragments Maranhão [1]. Such biomolecules are important for the development of studies in the fields molecular biology, medicine and pharmaceuticals, and also in developing treatments for various types of diseases and diagnoses Seo et al. [2],Lynch et al. [3], such as cancer and infectious diseases Baert et al. [4]; Rocha et al. [5]; Bumrela [6]; Huber et al. [7],therapies to combat rheumatoid arthritis and osteoarthritis Hughes et al. [8], against smoking Bevins et al. [9]; Peterson et al.[10];fighting drugs like methamphetamine Peterson, et al. [10] and cocaine Dickerson \&Janda [11]; combating the sequelae of alcoholism Bagasra et al. [12]; combating Alzheimer's Boado et al. [13]; Nisbetet al. [14]; detecting myocardial injury related Marti et al. [15]; diagnosis of pregnancy Payne Jr et al. [16]. Antibodies resulting from manipulation and recombination of variable fragments single chain ( $\mathrm{scFv}$ ) immunoglobulin, have been used in therapeutics and diagnostics, offering advantages over conventional antibodies Malecki et al. [17]; Wilkinson et al. [18]; Monnier et al. [19].
In ruminant animals, possessing synepthelichorial placenta (Igwebuike [20]; Pinto et al. [21]), the activity of trophoblast cells, especially the trophoblast giant cells, are related to the process of implantation of the conceptus and training of the placentome Pinto et al. [21]; Ealyet al. [22] and directly related to the recognition of the fetus by the maternal organism Shi et al. [23]; Roberts, [24]. This cellular activity induces the production and secretion of various specific molecular structures that are temporarily expressed during pregnancy Miguez et al. [25]; Machado et al. [26], but not all are known or have been isolated. Detection of these antigens or chemical markers is of great importance for breeding ruminant animals and especially for a greater understanding of the physiology and gene expression of trophoblastcells synepthelichorial placenta Roberts, [24]; Roberts et al. [27].

It is presented in this context, this work has as objective aconstruction of gene libraries of single chain variable fragments (scFv) antibody chicken (Gallus gallusdomesticus) placentome anti-ruminant animals and also to contribute to the creation of new knowledge on trophoblastcells and their effects on reproduction in animals synepthelichorial. These gene libraries will be the basis 
for future work, we will focus on the expression of recombinant biomolecules, which can be selected by affinity for the specific trophoblast cells in goats and sheep placentomes molecular markers.

\section{Materials and Methods}

\section{Immunization of animals and collection of samples}

Used in this study were macerated placentomas of female goats and sheep consistent with the first third of gestational development. The immunization was performed via the deep pectoral muscles at three Lhomann brown laying hens of 28 weeks old. Immunizations took place every fortnight, the first immunization was performed with the filtrate $200 \mathrm{mg}$ macerate placentome goats and sheep (GSP - Goat and Sheep Placentomes) plus complete Freud's adjuvant, 1:1. Over two immunizations were performed with the use of incomplete Freud's adjuvant, under the same conditions for the first immunization. In the process of construction of the gene library of goat and sheep placenta antiscFv mixture of macerated placentome of female goats and sheep was used, this procedure was done this way because of the great phylogenetic closeness existing between these two species. Fifteen days after the third and final immunization, totaling a trial period of 45 days, all chickens were anesthetized using a 5:1 ratio of Ketamine $(100 \mathrm{mg} / \mathrm{ml}$ or $50 \mathrm{mg} / \mathrm{kg}$ )and Xylazine $(20 \mathrm{mg} / \mathrm{ml}$ or $10 \mathrm{mg} / \mathrm{kg}$ ) following the animals were euthanized by ensanguinação. The spleens of these animals were isolated, identified, and stored at $-20{ }^{\circ} \mathrm{C}$ for future total RNA extraction. During the immunization eggs were collected and separated to the extraction of Y (IgY) immunoglobulins performed by using the commercial kit EGGstract ®IgY Purification System (Promega Corporation, Madison, USA), with subsequent measurement of the concentration by the method of Bradforf Bradford[28] and purification of IgY by electrophoresis in polyacrylamide gel with sodium dodecyl sulfate (SDS-PAGE).

\section{Extraction and isolation of total RNA}

Three fragments of spleen, 50mg, referring to the three chickens were used for extraction of total RNA by methodology TRIZOL reagent (Invitrogen, USA). The quantification of the concentration was carried out in a spectrophotometer (Power Wave NS2 BioTek Instruments, Inc.) at a wavelength of $260 \mathrm{~nm}$.

\section{Construction of cDNA molecules and the light chain (VL) and heavy chain (VH)}

The cDNA of the immunoglobulin G (IgG) was synthesized by using kit SuperScriptTM III Reverse Transcriptase (Invitrogen, USA) and dNTP Set (Fermentas Life Sciences, Maryland, USA), according to the manufacturer's instructions. Primers used for amplification of the variable regions VL and VH were prepared by BarbasIII et al. [29].VL regions of the immunoglobulins were amplified using the sense primer CSCVK-F (5'-GTG GCC CAG GCG GCC CTG ACT CAG CCG TCC TCG GTG TC-3'); and antisense CKJo-B (5'-GGA AGA TCT AGA GGA ACC CTG TAG GAC GGT CAG G -3'). For amplification of the
VH region, we used the sense primer CSCVHo-F (5'-GGT CAG AGA TCC TCT TCC TCT GTG GCC TTG ACG GAC GAG -3') and antisense CSCG-B (5'-GCC CTG GGC CTG GCC ACT AGT GGA GAT GGA GAC GGT GAC TTC CC-3') (Eurofins MWG Operon, Alabama, USA). The cDNA samples were pretreated with RNase A 5U/ $\mu$ l (Thermo Fisher SCIENTIFIC, USA), and the PCR reactions were designed to 50ng of each sample Barbas III et al. [29]. Considering the final volume of $50 \mu \mathrm{l}$ per amplification reaction, this was performed using $5 \mathrm{U} /$ $\mu \mathrm{l}$ Taq DNA polymerase (Fermentas LIFE SCIENCES, Maryland, USA); $1 \mathrm{mM} \mathrm{MgCl2;} 2$ mMdNTP Mix (Fermentas LIFE SCIENCES, Maryland, USA), 10x Taq buffer with KCl (100 mMTris-HCl pH 8.80, $500 \mathrm{mMKCl} /$ Fermentas Life Sciences, Maryland, USA), 30pmol/ $\mu \mathrm{l}$ of sense and antisense primer and free water RNA and DNA in order to complete the amplification reaction $50 \mu$ l. The buildings of the fragments VL and VH were made separately and each using their specific primers.

The programming of the recommended thermocycler followed by Barbas III et al. [29] beginning with an incubation at $94^{\circ} \mathrm{C}$ for 2 minutes. Compounds followed by 30 cycles by denaturing at $94^{\circ} \mathrm{C}$ for 02 minutes, annealing at $56^{\circ} \mathrm{C}$ for 15 seconds and extension at $72^{\circ} \mathrm{C}$ for 90 seconds, and the completion of the reaction cycle at $72^{\circ} \mathrm{C}$ for 10 minutes was used. The control reaction was performed by electrophoresis in $1 \%$ agarose gel and the result was further documented by using photodocumentator.

\section{Construction of single-chain variable fragments (scFv) by overlap-PCR}

The bands of fragments VL and VH were extracted from the agarose gel and purified separately with the aid of MinElute Gel Extraction Kit (QIAGEN). Following extraction of these products were further purified by QIAquick PCR Purification Kit (QIAGEN) and stored at $-20^{\circ} \mathrm{C}$. The Overlap-PCR is define the connection (or overlap) between fragments of the chain light (VL) and heavy (VH), constructed by forming a flexible peptide linker (VL-linker-VH) comprising the complementary tails of the connection between the sense primer (CSCVHo-F) heavy chain and anti- sense primer light chain (CKJo-B) used for amplification of fragments. The primers for the construction of scFv molecule of this study followed the description Barbas III et al. [29]: sense primer CSC-F (5'-GAG GAGGAGGAGGAGGAGGTG GCC CAG GCG GCC CTG ACT CAG -3') and antisense primer CSC-B (5'-GAG GAGGAGGAGGAGGAGGAG CTG GCC GGC CTG GCC ACT AGT GGA GG-3') (Eurofins MWG Operon, Alabama, USA). The final product was characterized Overlap-PCR with approximately 750 base pairs (bp).

The Overlap-PCR reactions were drawn for each sample 50ng of fragment VL and VH Barbas III et al. [29]. The PCR fragments

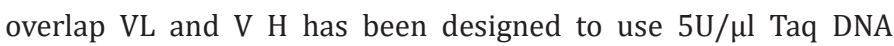
polymerase (Fermentas LIFE SCIENCES, Maryland, USA) $1 \mathrm{mM}$ MgCl2, 2 mMdNTP Mix (Fermentas LIFE SCIENCES, Maryland, USA), 10XTaq buffer with KCl (100 mMTris-HCl pH 8.80, 500 $\mathrm{mMKCl} /$ Fermentas LIFE SCIENCES, Maryland, USA), 30 pmol/ $\mu \mathrm{l}$ of 
sense and antisense primer and free water RNA and DNA in order to complete the reaction $50 \mu$ l Overlap-PCR.

The thermocycler was programmed for Overlap PCR reaction so that the activation reaction was carried out at $94^{\circ} \mathrm{C}$ for 60 seconds, following 30 cycles were performed 03 times with each cycle, the first time 2 minutes $94^{\circ} \mathrm{C}$, the second at $56^{\circ} \mathrm{C}$ for 60 seconds and a third at $72^{\circ} \mathrm{C}$ for 90 seconds, and the completion of reaction was conducted by one cycle at $72^{\circ} \mathrm{C}$ for 10 minutes. The control reaction was performed by electrophoresis on a $1 \%$ agarose gel and the results were documented through the use of photodocumentator.

\section{Statistical Analysis}

To compare the means of IgY the mixture of macerated GSPTukey's test at 5\% significance level was applied, using the statistical program ASSISTAT, version 7.6 beta/2011.

\section{Results}

\section{Measurement of immunization}

Measuring the success of immunization with GSP mixture was performed by assessing the concentration $(\mathrm{mg} / \mathrm{mL})$ of purified IgY from the yolks of immunized hens. Immunization with GSP solution showed average concentrations of $2.89 \pm 0.12,3.90 \pm 0.15$ and $4.24 \pm 0.21 \mathrm{mg} / \mathrm{mL}$, respectively for the 1st, 2nd and 3rd immunization. Immunizations performed with the mixture of macerated GSP showed the linear regression equation $y=0.195$ $\mathrm{x}+7.74$ and a coefficient of determination (R2) equal to 0.9916 (99.16\%), indicating an excellent fit for the relationship between immunizations and production of IgY performed, ie more than $99 \%$ of the production of IgY was established directly by increasing the number of immunizations with a mixture GSP.

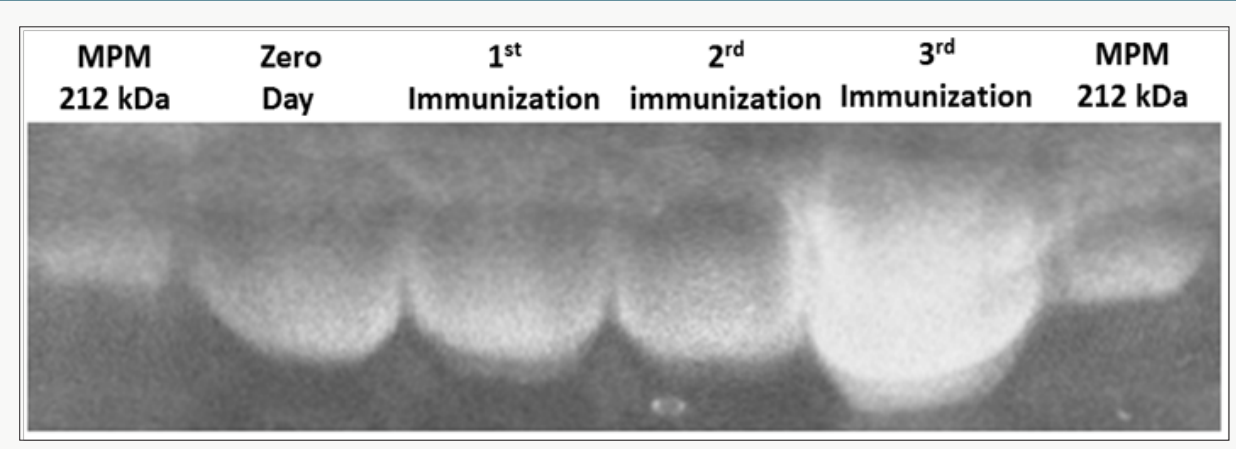

Figure 1: Purification results of immunoglobulin $\mathrm{Y}(\mathrm{IgY})$ anti-goat and sheep placentames in different stages of immunization Polyacrylamide $6 \%$ acrilamide gel electrophoresis.MPM, molecular weight marker $(\mathrm{kDa})$.

In the purification of IgY by electrophoresis on $6 \%$ polyacrylamide (SDS-PAGE) gel was identified IgY approximately $212 \mathrm{kDa}$ (Figure 1). We can observe an increase in the thickness of the band related to immunoglobulins, thus confirming higher levels of concentration of IgY, which corroborates with the increased concentration of IgY.

\section{Statistical Analysis}

The data in (Table 1) corroborates the mixture homogenized with the GSP, in the course of three immunizations promoted increased immunogenicity and consequent increase in the production of IgY as a response. This analysis was provided by the use of the Tukey test at a significance level of $5 \%$.
Table 1: Values followed by the same letter do not differ statistically among themselves. We have used the Tukey test at $5 \%$ significance level. (MSD = minimum significant difference; $\mathrm{GM}=$ general average; $\mathrm{CV} \%=$ coefficient of variation in $\%)$.

\begin{tabular}{|c|c|}
\hline Immunization & Medium concentrations of IgY to \\
\hline with GSP & immunization with GSP $(\mathrm{mg} / \mathrm{mL})$ \\
\hline Zero day & $1.98200^{\mathrm{d}}$ \\
\hline $1^{\text {st }}$ immunization & $2.89000^{\mathrm{c}}$ \\
\hline $2^{\text {rd }}$ immunization & $3.89400^{\mathrm{b}}$ \\
\hline $3^{\text {rd }}$ immunization & $4.24000^{\mathrm{a}}$ \\
\hline \multicolumn{2}{|c|}{$\mathrm{MSD}=0.33764 ; \mathrm{GM}=3.25150 ; \mathrm{CV} \%=5.73315$} \\
\hline
\end{tabular}

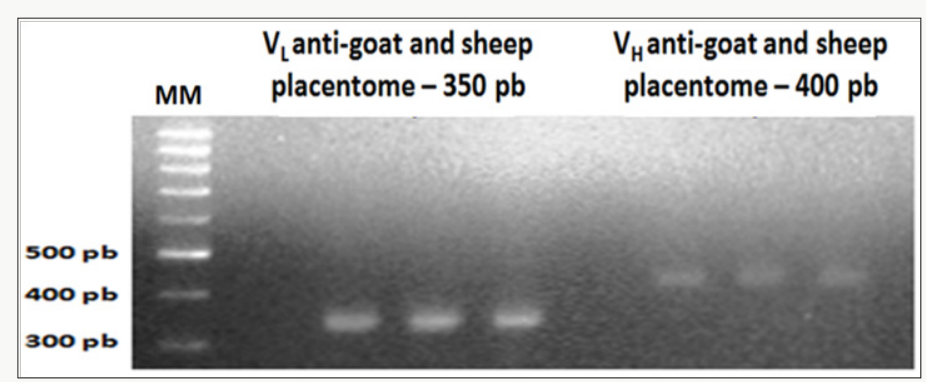

Figure 2: Amplification results of the light chain $\left(\mathrm{V}_{\mathrm{L}}\right)$ and heavy chain $\left(\mathrm{V}_{\mathrm{H}}\right)$ scFv fragments of chicken Immunoglobulin $\mathrm{G}$ (IgG), anti-goat and sheep placentome $1 \%$ agarose gel electrophoresis. 


\section{Amplification product of the cDNA of light chain (VL) and heavy chain (VH) scFv chicken immunoglobulin $\mathrm{G}$}

Referring to immunization with the macerated GSP after running on $1 \%$ agarose gel, the image was identified the presence of VL bands with 350pb and VH bands with 400bp (Figure 2).

\section{Product overlapping sequences of scFv fragments by Overlap-PCR}

Also referring to mixing with the mash GSP, after Overlap PCR reaction, the formation of fragments with approximately $750 \mathrm{pb}$ has been identified as a result of overlapping fragments and linearization VL and VH.

\section{Discussion}

In this study, chickens were immunized with homogenized in ruminant animals placentomas more Freund's adjuvant. As expected result was a DNA library of monoclonal antibodies (goat/sheep anti-placental) scFv fragments of immunoglobulin $G$ from total RNA extracted from leuocyte cells from the spleen of chickens. The methodology used in this study was efficient and effective in the development and construction of goat/sheep antiplacentomescFv library. The synthesis of the molecule overlapped scFv anti-placentome placenta caprine/sheep presented as result a band of 750 bp (Figure 3), equivalent to that described by Barbas III et al.[29], Roldanet al. [30].

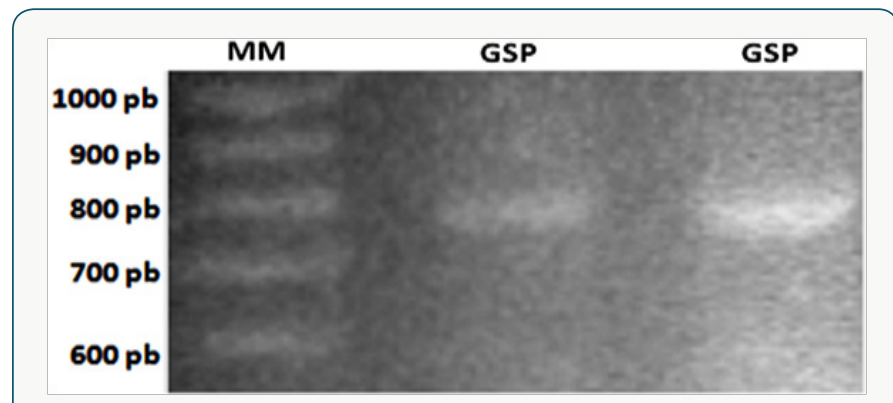

Figure 3: Overlap results of the light chain $\left(V_{L}\right)$ and heavy chain $\left(\mathrm{V}_{\mathrm{H}}\right) \mathrm{scFv}$ fragments of chicken immunoglobulin $\mathrm{G}$ (IgG) anti-goat and sheep placentome (GSP). 1\% agarose gel electrophoresis.

With respect to the effect of immunization and production of IgY, experimental procedures and similar results were reported by Gassmann et al. [31], in which chickens were immunized with 20 to $30 \mathrm{mg}$ of mammalian protein added to Freud's complete adjuvant. The results of 62 eggs extracted total amount of 4.0 grams of IgY and obtained as a final yield of approximately $130 \mathrm{mg}$ specific for a protein of mammalian cell cycle regulatory antibodies. Using the immunoblot technique identified that 20 days after immunization, IgY antibodies appeared, reaching a maximum production within 30 days after first immunization, maintaining a good level of production until 81 days, when the average was $72 \mathrm{mg}$ of IgY per yolk. These researchers obtained at the end of the experiment the mean concentration with standard deviation of 7.44 $\pm 0.27 \mathrm{mg}$ of $\mathrm{IgY} / \mathrm{mL}$ of yolk. For Meenatchisundaram et al. [32], IgY concentrations ranged from 0.85 to $7.60 \mathrm{mg} / \mathrm{mL}$ of egg yolk, throughout the immunization period. Already to Pauly et al. [33] variations IgY were between 3.0 to $8.0 \mathrm{mg} / \mathrm{ml}$ of yolk. Chui et al. [34] reached a mean value of $5.75 \mathrm{mg}$ of IgY per $\mathrm{ml}$ of egg yolk immunized as Barbas III et al. [29] had concentrations range from 55 to $80 \mathrm{mg} /$ egg yolk and $75 \%$ purity using the same extraction kit used in this study. In this study, average concentrations of finals were obtained $3.68 \pm .16 \mathrm{mg}$ of $\mathrm{IgY} / \mathrm{mL}$ in the yolk. One advantage of the IgY antibody production is that the required amount of antigen for high and long lasting for IgY yolk of immunized hens titration would be very low compared to immunization of other animals such as the rabbit Song et al.[35]; Hatta et al.[36]. When the result of IgY extract was applied to $6 \%$ polyacrylamide gel was characterized by bands at approximately $212 \mathrm{kDa}$ molecular weight. The literature describes this mass ranging from $180 \mathrm{kDa}$ immunoglobulin Meenatchisundaramet al. [32]; Warret al. [37]; Chalghoumiet al. [38] to $220 \mathrm{kDa}$ Hamada et al. [39].

Andris-Widhopf et al. [40] have also obtained cDNA fragments of approximately $750 \mathrm{pb}$ as a result of Overlap PCR reaction scFv fragments. These researchers used chickens immunized with a conjugate of bovine serum albumin (BSA) plus fluorescent and hapten reported as a result of the joining VLand VH, comprising the formation of a linker sequence (VL-linker-VH). They also emphasized that the VL-linker-VHproduct, corresponds to the scFvregion of immunoglobulin, has good applicability for use as befits its use with vector transfection.

In the bursa of Fabricius, the level of the complementarity determining regions (CDRs) of scFv fragments (light and heavy chain) derived from immunoglobulin G (IgG) from chicken and poultry in general, such mechanisms occur: the gene rearrangement and gene conversion somatic hyper-mutation. These mechanisms promote increased variability in this gene fragments due to the incorporation of genes pseudo and direct, acting in the maturation cell of B lymphocytes McCormack \& Thompson, [41]; Paramithiotis et al. [42]; Arakawa [43]. Thus the Overlap PCR allows the tool the final product, or the $\mathrm{scFv}$ fragment, a great increase in respect of gene variability, since it favors the increase of the combination of variable gene fragments, allowing the number of clones from a library of scFv generated by this method reaches to 1012 units Barbas III et al. [29].

cDNA libraries are indispensable to analyze the expression and function of genes and also in the study of protein function, this expression products. Hese information can be of great importance in understanding when and how certain genes are expressed in an cell type or organism. The continuous progress in the development of constitutive techniques of scFvgene libraries and the interest in their applications suggest that these tools will continue to be an important factor for the development of new recombinant biomolecules. 


\section{Conclusion}

This study was consolidated construction of gene library as a viable method for the construction of $\mathrm{scFv}$ recombinant biomolecules. The construction of gene libraries of recombinant scFv fragments of immunoglobulin G (IgG) chicken has great potential for use due to its high genetic variability, promoted by the mechanisms of gene rearrangement, gene conversion and somatic hyper-mutation occurring in fragments of varying chain light (VL) and heavy (VH). Thus, scFv fragments may be linked chicken techniques of molecular biology generation of biomolecules with high target-binding affinity. Caprine and ovine anti-placenta obtained by Overlap-PCR in this study biomolecules can be used to identify physiological aspects of trophoblast cells of caprine and ovine placenta, thus developing the function of these cell typespecific molecular markers.

\section{Acknowledgement}

The Foundation for Research Support of the State of Rio Grande do Norte (FAPERN) and the National Council for Scientific and Technological Development (CNPq) for funding this research project.

\section{References}

1. Maranhão AQ, Brígido MM (2011) Anticorpos humanizados. Biotecnologia, Ciência e Desenvolvimento 23: 38-43.

2. Seo H, Yamada, T, Hashimoto SI, Lin W, Ohta K (2007) Modulation of immunoglobulin gene conversion in chicken DT40 by enhancing histone acetylation, and its application to antibody engineering. Biotechnology and Genetic Engineering Reviews 24(1): 179-194.

3. Lynch CM, Hart BW, Grewal IS (2009) Practical considerations for nonclinical safety evaluation of therapeutic monoclonal antibodies. MAbs 1(1): 2-11.

4. Baert F, Noman M, Vermeire S, Assche GV, D'haens G, et al. (2003) Influence of immunogenicity on the long-term efficacy of infliximab in crohn's disease. N Engl J Med 348: 601-608.

5. Rocha RM, Nunes CB, Rocha GFS, Oliveira FN, Sanches FSF, et al. (2007) A comparison between the novel rabbit monoclonal antibodies ( $\mathrm{sp} 1$ and b644) and mouse antibodies for evaluating estrogen receptor in breast tumors. J Bras Patol Med Lab 43(6): 435-440.

6. Bumrela SB (2007) Monoclonal antibodies: an emerging biochemotherapeutic agent. Directory of Open Access Journals - DOAJ Journal Pharmaceutical 5:6.

7. Huber G, Bánki Z, Stoiber H (2014) Novel bifunctional single-chain variable antibody fragments to enhance virolysis by complement: generation and proof-of-concept. BioMed Research International 14.

8. Hughes C, Faurholm B, Dell'accio F, Manzo A, Seed M, et al. (2010) Human single-chain variable fragment that specifically targets arthritic cartilage. Arthritis Rheum 62(4): 1007-1016.

9. Bevins RA, Wilkinson JL, Sanderson SD (2008) Vaccines to combat smoking. Expert OpinBiolTher 8(4): 379-383.

10. Peterson E, Owens SM, Henry RL (2006) Monoclonal antibody form and function: manufacturing the right antibodies for treating drug abuse. AAPS J 8(2): E383-E390.
11. Dickerson TJ, Janda KD (2005) Recent advances for the treatment of cocaine abuse: central nervous system immuno pharmacotherapy. AAPS J 7(3): E 579-586.

12. Bagasra AO, Dorio HR, Kajdacsy-Balla A (1987) Functional analysis of T-cell subsets in chronic experimental alcoholism. Immunology 61(1): 63-69.

13. Boado RJ, LU JZ, Ka-wai E, Pardridge WM (2010) IgG-single chain Fv fusion protein therapeutic for Alzheimer's disease: expression in $\mathrm{CHO}$ Cells and pharmacokinetics and brain delivery in the Rhesus monkey. BiotechnolBioeng 105(3): 627-635.

14. Nisbet RM, Nigro J, Breheney K, Caine J, Nuttall, SD, et al. (2013) Central amyloid-b-specific single chain variable fragment ameliorates $A \beta$ aggregation and neurotoxicity. Protein Eng Des Sel 26(10): 571-580.

15. Marti V, Ballester M, Udina C, Carrió I, Alvarez E, et al. (1995) Evaluation of myocardial cell damage by in-111-monoclonal antimyosin antibodies in patients under chronic tricyclic antidepressant drug treatment. Circulation 91: 1619-1623.

16. Payne JrWJ, Marshall DL, Shockley TRK, Martin WJ (1988) Clinical laboratory applications of monoclonal antibodies. ClinMicrobiol Rev 1(3): 313-329.

17. Malecki M, Hsu A, Truong L, Sanchez S (2002) Molecular immuno labeling with recombinant single-chain variable fragment ( $\mathrm{scFv}$ ) antibodies designed with metal-binding domains. PNAS 99(1): 213-218.

18. Wilkinson IC, Hall CJ, Veverka V, Shi JY, Muskett FW, et al. (2009) High Resolution NMR-based model for the structure of a scFv-IL-1 $\beta$ complex potential for nmr as a key tool in therapeutic antibody design and development. J BiolChem 284(46): 31928-31935.

19. Monnier PP, Vigouroux RJ, Tassew NG (2013) In Vivo applications of single chain Fv (variable domain) (scFv) fragments. Antibodies 2(2): 193-208.

20. Igwebuike UM (2006) Trophoblast cells of ruminant placentas - a minireview. AnimReprodSci 93(3-4): 185-198.

21. Pinto LM, Ambrósio CE, Teixeira DG, Araújo KPC, Júnior JRK, et al. (2008) Comportamento das células trofoblásticas gigantes na placenta de vacas Nelore (Bosindicus-Linnaeus, 1758). RevBrasReprodAnim 32(2): 110121.

22. Ealy AD, Larson SF, Liu L, Alexenko AP, Winkelman GL, et al. (2001) Polymorphic forms of expressed bovine interferon- $\tau$ genes: relative transcript abundance during early placental development, promoter sequences of genes and biological activity of protein products. Endocrinology 142(7): 2906-2915.

23. Shi D, Kellems RE (1998) Transcription factor AP-2 gamma regulates murine adenosine deaminase gene expression during placental development. J BiolChem 273(42): 27331-27338.

24. Roberts RM (2007) Interferon-tau, a type 1 interferon involved in maternal recognition of pregnancy. Cytokine Growth Factor Rev 18(56): 403-408.

25. Miguez PHP, Cunha PM, Marques VB, Bertan CM, Binelli M (2005) Combination of estradiol $17-\beta$ and progesterone is required for synthesis of PGF2 $\alpha$ in bovine endometrial explants. AnimReprod 2(3): 172-177.

26. Machado RZ, Mineo TWP, LandimJrLP, Carvalho AF, Gennari SM, et al. (2007) Possible role of bovine trophoblast giant cells in transplacental transmission of Neosporacaninum in cattle. Rev Bras Parasitol Vet 16(1): 21-25.

27. Roberts RM, Green JA, Xie S (2005) Compositions and methods for early pregnancy diagnosis. Patent Application Publication, United States, pp. $1-67$. 
28. Bradford MM (1976) A rapid and sensitive method for the quantitation of microgram quantities of protein utilizing the principle of protein-dye binding. Analytical Biochemistry 72(1-2): 248-254.

29. Barbas III CF, Burton DR, Scott JK, Silverman GJ (2001) Phage Display: A Laboratory Manual. Cold Spring Harbor Laboratory Press, New YorkUSA.

30. Roldan CP, Tapia OZ, Araujo LJA, Miño CC, Sanchez AGD, et al. (2011) Identification of single Fv antibody fragment against Helicobacter pylori. Journal of Bacteriology Research 3(8): 138-145.

31. Gassmann M, Thommes P, Weiser T, Hubscher U (1990) Efficient production of chicken egg yolk antibodies against a conserved mammalian protein. FASEB J 4: 2528-2532.

32. Meenatchisundaram S, Shanmugam V, Anjali VM (2011) Development of chicken egg yolk antibodies against Streptococcus mitis-purification and neutralizing efficacy. Journal of Basic and Clinical Pharmacy 2(2): 108-114.

33. Pauly D, Dorner M, Zhang X, Hlinak A, Dorner B, Schade R (2009) Monitoring of laying capacity, immunoglobulin Y concentration, and antibody titer development in chickens immunized with ricin and botulinum toxins over a two-year period. PoultSci 88: 281-290.

34. Chui LW, Robin KR, Chow EYW, Sim J (2004) Immunological response to Mycobacterium avium subsp. paratuberculosis in chickens. Can J Vet Res 68(4): 302-308.

35. Song CS, Yu JH, Bai DH, Hester PY, Kim KH (1985) Antibodies to the $\alpha$-subunit of insulin receptor from eggs of immunized hens. J Immunol 135(5): 3354-3359.
36. Hatta H, Tsuda K, Akachi S, KimM, Yamamoto T (1993) Productivity and some properties of egg yolk antibody (IgY) against human rotavirus compared with rabbit IgG. BiosciBiotechnolBiochem 57(3): 450-454.

37. Warr GW, Magor KE, Higgins DA (1995) IgY: clues to the origins of modern antibodies. ImmunolToday 16(8): 392-398.

38. Chalghoumi R, Beckers Y, Portetelle D, Théwis A (2009) Hen egg yolk antibodies (IgY), production and use for passive immunization against bacterial enteric infections in chicken: a review. Biotechnology, Agronomy, Society and Environment 13(2): 295-308.

39. Hamada S, Horikoshi T, Minami T, Kawabata S, Hiraoka J, Fujiwara T, Ooshima $\mathrm{T}$ (1991) Oral passive immunization against dental caries in rats by use of hen egg yolk antibodies specific for cell-associated glucosyltransferase of Streptococcus mutans. Infect Immun 59(11): 4161-4167.

40. Andris-Widhopf J, Rader C, Steimberger P, Fuller R, Barbas III CF (2000) Methods for the generation of chicken monoclonal antibody fragments by phage display. J Immunol Methods 242(1-2): 159-181.

41. Mccormack WT, Thompson CB (1990) Chicken IgL variable region gene conversions display pseudogene donor preference and 5' to 3' polarity. Genes Dev 4(4): 548-558.

42. Paramithiotis E, Jacobsen KA, Ratcliffe MJH (1995) Loss of surface immunoglobulin expression precedes B Cell death by apoptosis in the Bursa of Fabricius. J Exp Med 181(1): 105-113.

43. Arakawa H, Buerstedd J-M (2004) Immunoglobulin gene conversion: insights from Bursal B cells and the DT40 cell line. DevDyn 229(3): 458464 .

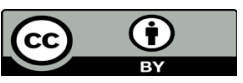

This work is licensed under Creative Commons Attribution 4.0 License

Submission Link: Submit Article

DOI: $10.32474 / C D V S .2018 .01 .000104$

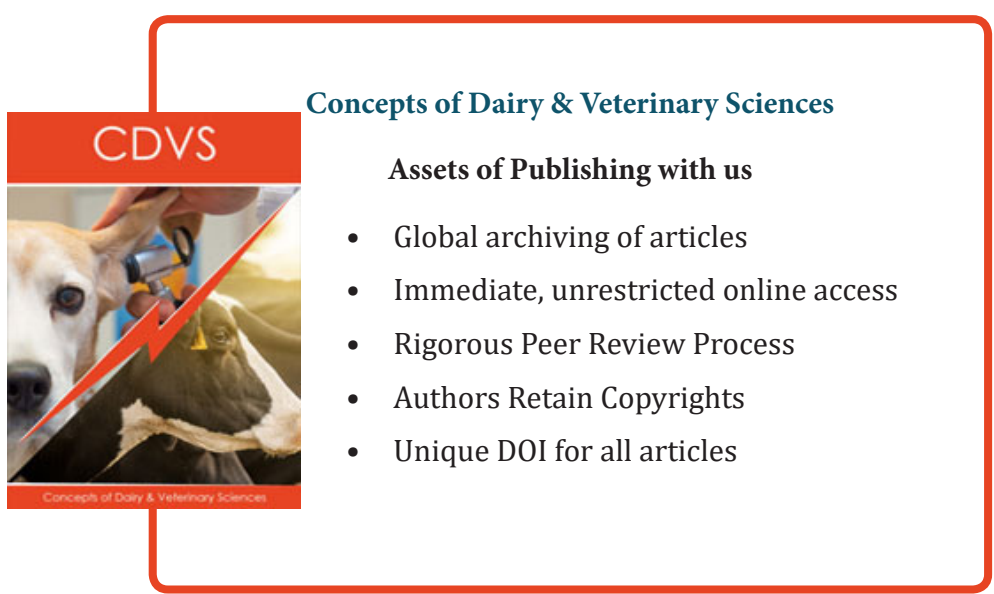

